\title{
Values of Social Sufism in the Short Story "Burung Kecil Bersarang di Pohon" (A Little Bird Nesting on the Tree) by Kuntowijoyo
}

\author{
Anwar Efendi \\ Faculty of Languages and Arts, Yogyakarta State University, Indonesia \\ Email: efendianwar68@gmail.com
}

\section{Doi:10.5901/mjss.2015.v6n4s2p93}

\section{Abstract}

This research aims at decribing the values of social Sufism in the short story "Burung Kecil Bersarang di Pohon" (A Little Bird Nesting on the Tree) by Kuntowijoyo. To reach the objective, heuristic and hermeneutic readings were conducted. The results of the research are as follows. First, the values of social Sufism is presented through the character of the old man-child, and the market-mosque as the setting. Second, the values of social Sufism is actualized through the portrayal of the importance of the balance of worship and work. The prayers directed for the life hereafter must be balanced with the working directed for the daily life. Third, the teaching of social sufism emphasizes the importance of keeping the horizontal and vertical relations. Vertical relation is for human-God relation, and the horizontal one is for human to human relation, and to other creatures on earth.

Keywords: Sufism, prayers, awareness on faith, and awareness on humanity

\section{Introduction}

There are three inner restlessnesses within a writer encouraging the creation of literary works. The first is metaphysical anxiety or the human relationship with the Creator (God). Second, it is social anxiety, which reflects the relationship between humans in the social structure. The third is existential anxiety, which describes efforts to face and try to selfresolve the problem (Kleden, 2004: 106). In addition, there are three aspects that can be sources of creation of literary works, namely: (a) religion, (b) society, and (c) the individual. In other words, literature is always dealing with human problems in relations to God, in conjunction with other human or nature, and in conjunction with the self.

Metaphysical anxiety is associated with human's effort to get to know the Creator (God). This is the efforts to the re-recognition of the nature of God because, only by remembering the Lord, will humans remember themselves, and only by self-exploration can humans understand their God. Religious experiences related to the feeling and human spirituality, such as feelings of sin, fear to God, and the God's glory can be employed as material or object in the creation of literary works (Anwar, 2007: 12).

Social anxiety is related to the presence of humans as social beings. Social reality related to social life, including social interaction between groups, social institution relations, social layer, power, authority and leadership, social change, and social conflict can be used as materials or objects in the creation of literary works. Moreover, problems faced by community such as poverty, crime, disorganized family, violation of norms can be the sources of the writing (Soekanto, 1997: xii).

Existential anxiety is closely related to human existence as an individual. Human problems that can be used as an individual substance or object in the creation of works are the issue of love, beauty, suffering, justice, responsibility, outlook on life, hope, and anxiety. Those individualized impulses enhance creative text motifs, such as the heroic novel, poem about independence and freedom, and works against all forms of oppression and tyranny.

As described above, one of the sources of inspiration for the creation of literary work is a metaphysical anxiety associated with awareness of divinity. In the development of literary works in Indonesia, Kuntowijoyo is well-known as one of the authors who creates many works using metaphysical anxiety. Kuntowijoyo through his works much lifts and actualizes religious themes in the context of people's lives (Wangsitalaja, 2001a). Kuntowijoyo focuses his literary works as a medium towards achieving transcendental aspects (divinity). To achieve this transcendental aspect, he mostly employs the social aspect (humanity).

Kuntowijoyo has his own characteristics in picking and expressing religious themes. In his work, he does not display the religious themes literally and doctrinal, but unites them in the framework of literary aesthetics (Anwar, 2005). 
Thus, the literature does not get stuck on dogmatic and formalistic missionary activities. Literary work can serve as a means to think for the audience and provide an alternative bid to make decisions when faced with a problem (Sayuti, 2005: 43). Literary works should be able to provide a balance between social and spiritual themes, between depth of worship and involvement in humanitarian issues, and between the human activity and the religious experience (eschatology) (Wangsitalaja, 2001b).

In the Islamic perspective, the concept of balance between the spiritual theme (divinity) and social themes (humanity) is identical with concept of social Sufism. Social Sufism does not separate the world and the life hereafter. In this case, the attitude of the ascetic (zuhud 'isolating from the affairs of the world') which is at the core of Sufism should be interpreted according to the circumstances. Therefore, an individual's awareness of divinity must be accompanied by an awareness of the social nature of humanity (Syukur, 2005: 14).

It is interesting to study the realization of the values of social Sufism in literary works written by Kuntowijoyo. This paper discusses the issue by studying of his short story entitled "Burung Kecil Bersarang di Pohon" which was published in a collection of short stories Dilarang Mencintai Bunga-Bunga (Kuntowijoyo, 1992: 181). Kuntowijoyo's efforts put his works as the embodiment of actualization and contextualization of religion in human life significantly. Hilmy (2008:108) calls these efforts "bringing God in the public sphere", which attempts to integrate spiritual and worldly affairs in various dimensions of human lives.

\section{Theoretical Framework}

Sufism as a phenomenon in the history of Islam begins with the dissatisfaction to the religious practices which tend to follow formalism and legalism (Renard, 2005). In addition, Sufism is also a moral movement to criticize social, political, and economic inequality carried out by Muslims. In this case, Sufism is understood as one of the solutions offered by the Sufis to address the above issues. To deal with the formal tendencies and religious legalism, a transformation of physical action toward inner action is foregrounded. Isolation from the bustle of the world is meant to cope with the behavior of glorifying prosperity. The offer is then known as zuhud or ascetic behavior, the behavior putting humans away from the world and hereafter oriented (Syukur, 2005: 13).

In essence, Sufism is part of Islam which is a manifestation of insan as one of the three other Islamic framework, namely faith (Iman), Islam and Ikhsan. Therefore, the behavior of Sufism must remain within the framework of the Islamic law. As a manifestation of ihsan, Sufism is the individuals' deep appreciation on their religion that allows them the spiritual liberation. Through Sufism, humans can recognize themselves leading to end of knowing their God (Syukur, 2005: 12).

So far, ascetic behavior as the core of Sufism lies in the inner region (inner life). The question then, is it relevan to associate ascetic behavior with the life in modern society? Is ascetic behavior appropriate if it is associated with the position of man as an individual and as part of a community?

Those questions can be answered by giving a new meaning and understanding of the behavior of the ascetic in Sufism (Raudvere \& Stenberg, 2009). In Islam, human values can be understood when all outer and inner behaviors are oriented to God. On the other hand, at the same time, such behavior can bring a concrete impact on efforts to improve the human values. In short, human beings cannot be understood without their association to God and to other human beings in social life.

In line with the above description, Syukur (2005: 13) puts forward the concept of social Sufism as one of the contemporary understandings of the teachings of Sufism. Social Sufism does not split nature from law (figh) and keeps engaged in life and earthly life, and does not separate the world and the hereafter. In this case, ascetic attitude as the core of Sufism can be interpreted in accordance with the circumstances.

Ascetic attitude is essentially a form of Sufists' reaction against social inequality, economic and religious practices at that time. Therefore, the formulation of the ascetic attitude may vary depending on the demands of the time. Sufism has to react to circumstances that occurred at that time to find out best moral solutions and by self-isolating from the material oriented (wealth) and power. Thus, it would seem that the actual values of Sufism is grounded and applicable to the problems faced in its time (Howell, 2007).

Substantially, the values of Sufism has a social dimension, namely futuwwah and al-itsar (Syukur, 2005: 16). The term futuwwah, referring to a knight, is from the word fata which means youth. At present, the meaning has developed into ideal, noble and perfect men. Futuwwah can also be interpreted as a man who is friendly and generous, patient and steadfast against temptation. A knight in Sufism is characterized by behaviors of unyielding; ease the difficulties of others, sincere for Allah. A knight must always try to appear with anticipatory attitude towards the future in a responsible manner.

Al-itsar can be understood as a meaningful action or behavior that is more concerned on others than himself. The explanation of the meaning of al-itsar refers to the Quran, Surat al-Hashr verse 9. The verse is about the residents of 
Medina (Anshor) who provide aid to the settlers of the city of Mecca (Muhajiirin). Anshor puts more priority to the interests of the Muhajirrin (the immigrants who came from the city of Mecca) and would settle down in the city of Medina (Syukur, 2005:16).

Furthermore, the concept of al-itsar also refers to the Hadith of the Prophet Muhammad, which reads "At best man is useful for other human beings". As a social being, a Muslim is ordered to provide relief and assistance to others (Qardhawi, 2001).

In the perspective of psychology, al-itsar can be compared with the behavior of altruism, which is a voluntary action conducted by a person or group of people to help others without expecting anything in return. Altruistic behavior is only based on the desire to do good deeds for others (Mifune, 2009).

In the context of today's modern society, social Sufism is not a masking tape, but should be active in the middle of the development of the community and the nation. Social Sufism is no longer solitude (uzlah) or seclusion (exile 'khalwat') from all forms of the crowds. In contrast, the behavior of Sufism is supposed to tell people to be active totally in the economic, social, and political life. Therefore, the role of the Sufis should be more empirical, pragmatic, and functional in looking at and responding to real life. Living the teachings of Islam through Sufism should not be reactive in nature, but active to give direction to people. The path of Sufism becomes one of the forms of social responsibility, the obligation to carry out tasks and respond to contemporary social problems (Syukur, 2005:21).

\section{Method}

The source of data in this study is a short story entitled "Burung Kecil Bersarang di Pohon" which is written in a collection of short stories Dilarang Mencintai Bunga-Bunga by Kuntowijoyo (1992). The data were in the form of exposure to the language as a discourse or narrative text messages that cover social Sufism. The data collection was done by reading and recording. Data analysis involves two aspects: (1) structural aspects and (2) the genetic aspects of literary works. The first stage of analysis activities revealed the content of the values of social Sufism through the identification of structural elements of the story. This phase was to find the description of the values of social Sufism that are conveyed by Kuntowijoyo through means of (the structure of) literature. In the semiotic perspective, the first phase is referred to heuristic readings. The second stage of the analysis was related to the socio-cultural aspects surrounding the writer: aspects related to the socio-cultural reality in the community referenced by the author in writing the literature. The data analysis was enriched with the concept of Sufism in the Islamic perspective derived from the Quran and Hadith. In a semiotic perspective, this phase is referred to hermeneutic readings.

\section{Discussion}

\subsection{The Synopsis}

The important figures in the short story are an old man and a little boy. The old man is a Professor of Tauheed in a prestigious university. On that occasion, he was supposed to preach and became a priest of Friday prayers at a mosque. At the end, he could not perform the task as Khotib and Imam. He failed because he was busy helping the little boy to catch a bird. This made him late to the mosque. When he arrived at the mosque, the Friday prayers was completed.

The story begins on a Friday afternoon. The old man was wearing kopiah (a cap commonly worn by Moslems) and a white shirt and golden-style thread sarong with a rug on his shoulder. This appearance symbolizes cleanliness and purity as the requirement to perform a Friday prayer in the mosque. On his way to the mosque, he kept maintaining the cleanliness of clothing and equipment worn from dirt and uncleanliness. To save the time, he passed through the market as a short cut. In his every step, he felt that it was weird witnessing many traders who did not care about the Friday prayers. The market was full of merchants who were always rushing, greedy looking face, wild sight, and only money oriented. The old man assumed that they did not think about their relationship with the Almighty. He wanted to warn them to stop working for a while just to attend the Friday prayer which was mandatory for Muslims.

When passing through the market, the old man felt uneasy. He feelt doubt about his command to the people in the market. He thought what if he himself was a marketer. Could he do the activity in the market such as the merchants? As a professor whose life was relatively fulfilled, leaving an hour off office was not a matter. For the people in the market, that was the serious loss. He had to admit that it was easy for him but not for the people in the market. People could close the university and remain prosperous, but one could not close the market, workshop, and factory.

After passing through the market, the old man met a little boy who wanted to catch a small bird. The little boy eyes were clear and plain. He did not have any heart to let a small child crying and decided to help catch the bird. 
The old men seemed to be spellbound by the act of helping. He seemed to forgot his main task as the preacher in a Friday prayer. The old man finally reached the mosque late, so he could not peform as a Friday preacher. Arriving at the mosque, the prayer was over. A striking mind attacked this Professor of tauhid. The old man felt that he had made a mistake by having more concern on helping the little boy than the liabilities to the preacher and Imams of the prayers.

$\mathrm{He}$ also felt that there was a relief in his heart. He feels confident that the decision to help the little boy was not a mistake. The act of helping the little boy had reminded the old man of the obligation to maintain relationships with fellow human beings. As a man, the old man finally realized that the longing for God (awareness of transcendence) is in an equal pleasure with longing for humans (human consciousness).

\subsection{The Balance between Worshipping and Working}

The principle of social Sufism is in line with the principle of unity of command to be faithful and to conduct pious deeds. In Quran, a series of calls or orders instruct people to be faithful to God and to do good things to humans. In Quran, Surah Al-Baqarah the second verse, it is mentioned that to become Mutaqin, men must have faith (iman), 'believe in the Unseen', establish prayers (sholat), and pay alms (zakat). The verse confirms the existence of trilogy of basic values of Islam, that is, faith (Iman) - prayer (Sholat) - alms (Zakat).

Based on the basic values above, it can be concluded that in Islam there is the assertion that faith must be culminated in charity, and in action. Aspect of faith (tauhid) must be actualized, so that the center of the Islamic faith is God, but the end of the actualization is human (Kuntowijoyo, 1999: 167). Thus, Islam makes monotheism as the center of value orientation, while at the same time sees humans as the purpose of the transformation of values.

In accordance with the Islamic paradigm as a blessing to all the worlds, the expression which is in accordance with the principles of Islam is an expression giving the real goodness of life, especially human. Therefore, the things disturbing the good of human life, such as ignorance, poverty, and underdevelopment must be eliminated. Islam must liberate humans from these things in order to create a civilized society.

Social Sufism in essence is the realization of the Prophet's teachings about the importance of the balance betwen hereafter affairs (worship) and world affairs (work). Social Sufism is a translation of one of the Hadiths related to human activity. In a Hadith narrated by Turmudzi, Rosululloh States: I'mal dunyaka kaannaka li li ta'ishu abadan wa'mal akhrotika kaannaka tamutu ghodan. Earn money (working) for your world as if you'll live forever and pray for the next life (worship) as if you will die tomorrow. The Hadith emphasizes the importance of work activities to meet the needs of living in the world. On the other hand, the activity of work that must be balanced with the activity of worship as one of the forms of human consciousness that leads to the realm of immortality (hereafter) after death later (Izutsu, 2003).

In the short story "Burung Kecil Bersarang di Pohon", the conception of worship is shown by the symbolism of the mosque, while the conception of working is through the symbolization of market. Mosque is a space for prayers or prostrating. In this context, the mosque is synonymous with religious activities. Furthermore, the market becomes a place in which the seller and the buyer conduct their transaction, a deal in the buying and selling activities. In this context, the market is a symbol of economic interest (Kuntowijoyo, 2006:131).

The balance between religious activities and working in the conception of Islam reflects the values that working is not solely to accumulate wealth and riches, but as capital to perform perfectly pious charity. One of the pious charities is the command to pay alms (zakat). The existence of an order to pay alms marks human importance to work, because by working humans can have considerable property. Adequacy of ownership of property is the reasons of the command.

The symbolic relation between religious activities and working activities was presented through the mosque and market as the setting of the story. The old man passed the market in his way to the mosque. In the market that the old man found that many people were busy with loads of transactions and forgot their obligation to attend the Friday prayer. The following quote confirms this .

\footnotetext{
"He felt something weird whenever he passed through the market. If it had not been to shorthen the way, he woudn't have passed the market. The traders were seen in infatuation. Can they forget their God? They are always in a hurry, greedy faces, wild eyes: money. Can't they just take a minute to think about their relation to God? Only a minute, no more than an hour in this Friday noon" (Kuntowijoyo, 1992).
}

The above quotation illustrates the importance of the balance of worship and work. In its terminology, religious activities are geared to the interests of the life hereafter, while the work is directed to the interests of the life of the world. In the Islamic view, both of these have the same important position and should be treated in a balanced manner. In this context, human life should not be oriented only to the interests of the afterlife so that his whole life just filled with activities 
of religious rituals. Instead, humans are also prohibited from using the whole time just to work and for the sake of the needs of the world alone.

Al-Quran affirms the recommendation to perform rituals properly and immediately after worship we are encouraged to work. Quran Surat Al-Jumu'ah verse 9 confirms the order to immediately perform worship (Friday prayers) if the time has come and immediately leave the bustle of work, including the buying and selling activity in the market. Complete verse 9 Quran Surat Al-Jumu'ah is as follows.

"O you who believe, when the call is made for prayer on Friday, then hasten to the remembrance of Allah and leave off trading; That is better for you, if you know".

Furthermore, the command to perform work activities following completion of worship (Friday prayer) is confirmed in the Quran Surat Al-Jumuah verse 10. The complete Quran Surat Al-Jumu'ah verse 10 reads: "But when the prayer is ended, then disperse abroad in the land and seek of Allah's grace, and remember Allah much, that you may be succesfull". The verse reaffirms the importance of a balance between the activity of worship and work activity, between the interests of the world and hereafter.

After the completion of worship, people are ordered to work and seek a living in accordance with the job and their respective professions. In a broader perspective, the work activity can be interpreted as a form of worship in the presence of God the Almighty. As stated in the Quran Surah Al-Insyiqoq, verse 6: "O man! Surely you must strive (to attain) to your Lord, a hard striving until you meet Him".

\subsection{The Balance of Awareness on Faith and on Humanity}

The balance between awareness on faith and on humanity is basically one of the marks of the perfect creation of humans. Humans who are created in the best shape, both physically and mentally, but they does not guarantee the quality of their life. Only faith and good deeds that can keep all the quality of human life that has been bestowed by God. Quran Surat At-Tin, verse 4-6, explains that God creates human in his best shape, but he will be returned to the lowly place if he is not faithfull and conducts pious deeds.

"Certainly We (God) created man in the best make. Then we render him the lowest of the low, except those who believe and do good, so they shall have a reward never to be cut off" (At-Tin: 4-6).

Humans who are at the beginning of creation have a degree of glory and virtue, by the end of life, can fall to the lowest degree. It can be avoided if they can preserve the character of glory manifested in a strong faith in God (verticalspiritual aspect) and positive actions towards each other (horizontal-material aspects). Glory and virtue throughout the real man is a provision to make the perfect life.

In this context, social Sufism principle is analogous to the execution of daily prayer (sholat). Worship prayer begins with takbiratul ihram and ends with greetings (al-sholatu almuftatahu takbiratul bi al-ihram, mukhtatamatu i wa al-taslim). Takbiratul ihram marks man's relationship with God with the utmost confidence that Allah is God the Exalted and the Mighty.

Furthermore, the greeting at the end of the prayer indicates that after remembering Allah (supplications/taqarroub), people are warned to remember the others, turn to the right and to the left.

Thus, the whole worship of God must be balanced with love, respect, love to our neighbors. Humans who are fortunate are the good men and can make others do good, if they can purify others and educate others, and they can make others succeed and if they are rich they can relieve the suffering of others. This is in accordance with the hadith of the Prophet: khairunn nassi anfa' uhum lil nassi (the best man is the one who can be the most beneficial for another man).

In the short story, social Sufism is about the importance of the balance between awareness of divinity (worship) and the consciousness of humanity (muamalah) represented by the relationship between the old man character and the character of little boy. After passing through the market, the old man met a little boy who wanted to catch a small bird. Under the tamarind tree, the little boy looked and pointed at bird's nest in a tree. The old man comforted him and promised to take the bird's nest in the branches. With great difficulty, the old man went up to the tree and at that time he did not care anymore about his clothes. The excerpt below provides an illustration of the above condition.

"A cry made him stop. Who is crying? Under the tamarind tree, a boy looking at a height. When the man looked at him, the boy was pointing upwards. The tree was tall and lush, causing coolness on that afternoon. The man rubbed the 
boy's head. "What?," the boy pointed upwards. "Bird", he said. "Oh, yes. There are sounds. It is a small bird, Grandchild" (Kuntowijoyo, 1992).

When looking at the small child crying, the old man took a pity and sought to help. The old man wanted to help the little boy to catch the bird nesting in the trees. At that moment, he felt a sort of happiness in him. The old man remembered his childhood that he needed to steal time to be able to play around with their peers. One of the favored games was catching birds by setting a trap. He could feel how happy the little boy was when he could catch the birds.

For a moment, the old man was in a doubt. He finally helped catch the birds that nested in the tree. He was aware that his white shirt was possibly exposed to dirt. Moreover, the time was right before noon where the Friday prayer was about to begin. He was supposed to be in hurry since he was the preacher in the prayer. Finally, he decided to help the little boy catch birds nesting in trees. The following quotation confirms that situation.

"When he thought how he could best climb the tree, he was nervous. The white dress he put on that day remided him something. But, the sudden happiness and hope on the birds erased it. He put off his sandals, threw away the rug, and folded the sarong. He was then on the top of the tree" Kuntowijoyo, 1992.

The old man finally reached the mosque late, so he could not perform to be a preacher and priest at Friday prayer. This professor has strange mind thinking perharps the little boy was the satan assigned to disrupt his prayers. However, other thought arises immediately denying his own previous thought. The little boy was really the son of man, so that he gets enlightenment of valuable experience in her life. The old man realizes that the activity of worship must be balanced with social activities as a form of awareness of himself as a social being. It is reflected in the following quotation.

"He went to get wudlu. His face was beaming. People were still gathering outside, when he entered the mosque. The experience that day must have been designed by God. He did not hesitate. What a wonderful way of Your (God) teaching. The little boy is the son of man. He misses all the children, birds and even the crowd of the market. Now, he misses Him (God)" (Kuntowijoyo, 1992).

With special way, Kuntowijoyo meets two opposing worlds in a philosphical synthesis. At a glance, spiritual life is different from socio-empirical life and it seems that they cannot be united. In his work, Kuntowijoyo presents two opposing poles not to be opposed but to be dialectically presented so that it results in synthesis (Anwar, 2007:67).

The essence of social Sufism embodies in the human position as creatures of God and at the same time as the representative of God on earth. It asserts essential human relationships, and the relationship of man with God and fellow human beings. Devotion to God is not solely determined by the intensity and quality of transcendental divine piety, but also by the measure of the intensity and quality of the devotion in humanitarian services. The teachings of Islam is not just about keeping a good relationship with God formally but also a harmonious relationship with servants and His (God) other creations.

The man's decision to help the little boy catch the bird in the tree can be interpreted as a desire to be directly involved in the problems of human life. The awareness as a social creature encourages people to do things for human beings. Human life must be at the level of the balance between the vertical life (transcendence) and horizontal life (social-empirical). Therefore, awareness of divinity through extreme Sufism, like solitude (exile) and celibate (not married) is forbidden in Islam (Hanafi, 2007).

\section{Conclusion}

Based on the above discussion conclusions can be formulated as follows. First, the short story Burung Kecil Bersarang di Pohon features social Sufism through dialectic structural elements used, namely (a) the character of the old men and the little boy, and (b) the setting of the market and the mosque. Second, the social Sufism is actualized through the balance of the importance of religious activities and work. The worship directed to the interests of the life hereafter must be balanced with the work within the framework of the activities run in the life of the world. Third, the social Sufism emphasizes the importance of maintaining a relationship that is both vertically and horizontally. Vertical relationship serves as the embodiment of man's relationship with God. The horizontal relationship serves as the embodiment of human relationships; relation by humans to other humans and with other creatures in this world.

Following this conclusion, the suggestions are as follows. First, in the middle of the pace of globalization, literature featuring the theme of social Sufism is important to be actualized. Nasr (1994) explains that modern man has lost the vision of divinity so a feeling of emptiness and alienation in his life easily attacks him. The literature that offers 
social Sufism is expected to be a void filler soul and eliminate alienation experienced by humans (Hadi, 1999: 23). Second, the literature that offers Sufism can be used as learning materials in schools in order to develop the character of the students. Literary works can be used as an aesthetic reflection for students to rebuild their religious, transcendental, and spiritual aspects within the individual, family, community, and nation (Nasr, 1987).

\section{References}

Anwar, M.W. (2005). "Kuntowijoyo, Menjejak Bumi Menjangkau Langit". Dalam Majalah Satra Horison. Edisi XXXIX/5/2005, Mei 2005 Anwar, M.W. (2007). Kuntowijoyo: Karya dan Dunianya. Jakarta: Penerbit Grasindo

Hadi, A. (1999). Kembali ke Akar Kembali ke Sumber. Jakarta: Pustaka Firdaus.

Hanafi, H. Dkk. (2007). Islam dan Humanisme, Aktualisasi Humanisme Islam di Tengah Krisis Humanisme Universal. Yogyakarta: Pustaka Pelajar.

Hilmy, M. (2008). Islam Profetik, Substansi Nilai-Nilai Agama dalam Ruang Publik. Yogyakarta: Penerbit Kanisius.

Howell, J. D. (2007). "Modernity and Islamic Spirituality in Indonesia's New Sufi Network" in Sufism and the modern in Islam Edited by Martin van Bruinessen and Julia Day Howell. New York: I.B. Tauris \& Co Ltd.

Izutsu, T. (2008). God and Man in the Quran, Semantic of the Quranic Weltanschauung. Kualalumpur: Islamic Book Truts

Kleden, I. (2004). Sastra Indonesia dalam Enam Pertanyaan: Esai-esai Sastra dan Budaya. Jakarta: Pustaka Utama Grafiti.

Kuntowijoyo. (1992). Dilarang Mencintai Bunga-bunga. Jakarta: Pustaka Firdaus.

Kuntowijoyo. (1999). Paradigma Islam: Interpretasi untuk Aksi. Bandung: Mizan.

Kuntowijoyo. (2006) Maklumat Sastra Profetik. Yogyakarta: Grafindo Litera Media

Mifune, N. (2009). "Altruism Toward in-group Members as a Reputation Mechanism". Evolution and Human Behavior, 31, 109-117.

Nasr, S. H. (1994). Islam: Religion, Histoy, and Civilization. HarperCollins e-books

Nasr, S.H. (1987). Islamic Art and Spirituality. Albany: State University of New York Press.

Qardhawi, Y. (2001). The Impact of Iman in the Life of the Individual. Nasr City: Al-Falah Foundation for Translation.

Raudvere, C. and Stenberg, L. (2009). Sufisme Today: Heritage and Tradition in the Global community. New York: I.B. Tauris \& Co Ltd.

Renard, J. (2005). The A to Z of Sufisme. Lanham: Scarecrow Press.

Sayuti, S.A. dkk. (2005). Penulisan Kreatif Sastra. Yogyakarta: Penerbit Hanindita.

Soekanto, S. (1997). Sosiologi Suatu Pengantar. Bandung: Rajawali Press.

Syukur, HM. A. (2005). Tasawuf Sosial. Yogyakarta: Pustaka Pelajar

Wangsitalaja, A. (2001a). "Kuntowijoyo: Bermula dari Sebuah Surau". Majalah Horison, Edisi Februari 2001. hlm 24-28.

Wangsitalaja, A. (2001b). "Kuntowijoyo: Dua Budaya Tiga Resep". Majalah Horison, Edisi Februari 2001. hlm 24-28. 